\title{
The motivation of farmer group members in utilizing urban yards in covid-19 pandemic in Yogyakarta City, Indonesia
}

\author{
Retno Wulandari ${ }^{1,2^{*}}$, Roso Witjaksono ${ }^{1}$, Ratih Innekewati $^{1}$, and Hilmi Fauzan Dzikri ${ }^{2}$ \\ ${ }^{1}$ Program of Extension and Development Communication, School of Post Graduate Studies, \\ Universitas Gadjah Mada,55284, Jl. Teknika Utara, Pogung, Sinduadi, Mlati, Sleman, Yogyakarta, \\ Indonesia \\ ${ }^{2}$ Department of Agribusiness, Universitas Muhammadiyah Yogyakarta, 55183 Jalan Brawijaya, \\ Kasihan, Bantul, Yogyakarta, Indonesia
}

\begin{abstract}
During the Covid-19 pandemic, there has been an increase in people using their yards in urban areas. This study aims to describe the motivation of farmer group members in using urban yards during the Covid19 pandemic and analyze their motivation factors. The research was conducted in Yogyakarta City by determining a sample of 45 farmer group members using multistage random sampling. Descriptive analysis was applied to describe the motivation of farmer group members in using urban yards during the Covid-19 pandemic. Analysis of the Spearman Rank Correlation Coefficient was implemented to analyze their motivation factors. This study unveiled that the motivation of farmer group members in utilizing urban yards seen from the motivation of existence, relatedness, and growth belonged to the high category. The results of the Spearman Rank Correlation Coefficient analysis revealed that motivation factors of the farmer group members comprised age and the role of the group leader, extension workers, and information technology.
\end{abstract}

\section{Introduction}

The Coronavirus, which has spread to various parts of the world, impacts the Indonesian economy, both in terms of trade, investment, tourism, and even the agricultural sector. The impacts include a decline in purchasing power caused by decreased income for the productive sector [1]. On the other hand, government policies on the Covid-19 pandemic have impacted the number of laid-off workers. This situation considerably shook the economy nationally and even regionally to the countryside. Accordingly, several sectors must be enhanced to keep the Indonesian economy running. In this case, the agricultural sector has been encouraged as the primary source of livelihood for the community [2].

The sustainability of urban agriculture is strongly influenced by natural [3] and human resources [4]. Natural resources include the availability of land, planting media, and water, while human resources influencing the development of urban agriculture are the agricultural

${ }^{*}$ Corresponding author: retno.wulandari@umy.ac.id 
actors themselves, namely members of farmer groups [5]. Agriculture in urban areas can improve air quality and reduce city heat; besides, household organic waste can be processed and used for agriculture [4]. At the same time, the use of yards also provides aesthetic and psychological benefits as a means of recreation.

The economic, social, cultural, and psychological conditions of each household in implementing an innovation are different [6]. In heterogeneous urban communities, attitudes to the environment are different for each individual and household, thus causing the different motivations of urban communities in using yards [7]. The use of yards can be sustainable and must adjust to the motivation of the community. Environmental motivation is the primary motivation for people in several big cities in carrying out agriculture [8].

During the Covid-19 pandemic, there have been many differences behind the motivations of members of urban farmer groups. According to [9], the economic motivation underlies urban communities in farming, including as a source of family food, reducing spending, and increasing household income. The lack of green open space and severe air pollution in urban areas also disrupt public health in the short and long term [10]. Far food sources raise concerns about the quality of their food [11]. Urban communities recognize that the food they produce is fresher, more nutritious, and healthier [12]. However, the broader health benefit is how farming in yards helps them psychologically instill discipline and patience as well as maintain physical health. Health benefits are also one of the motivations influencing farmer group members to utilize urban yards [13]. Hence, urban agriculture studies continue to be developed concerning environmental, economic, health, and social issues [14].

The use of yards for agriculture in urban areas has great potential and provides many benefits. Its location can be distinguished in the city center (intra-urban) and the outskirts of the city (peri-urban). The economic, social, cultural, and psychological conditions of each household in implementing an innovation differ [15]. In heterogeneous urban communities, attitudes to the environment are different for each individual and household, resulting in the different motivations of urban communities in using yards. Moreover, the use of yards can be sustainable and must adapt to the motivation of the community [16]. Environmental motivation is the primary motivation for people in several big cities in implementing urban agriculture [17]. Agriculture in urban areas can improve air quality and reduce city heat. Besides, household organic waste can also be processed and used for agriculture. At the same time, the use of yards also provides aesthetic and psychological benefits as a means of recreation [18]. The economic motivations that underlie urban farming communities include providing family food, reducing spending, increasing household income, and reducing transportation costs [19]. Lack of green open space and severe air pollution in urban areas will definitely disrupt public health in the short and long term. Far food sources raise concerns about the quality of the food they consume. Urban communities recognize that the food they produce is fresher, more nutritious, and healthier. Nevertheless, the broader health benefit is how farming in yards helps them psychologically instill discipline and patience and maintain physical health. Health benefits become an influencing motivation to use yards in urban areas. Another benefit of agriculture in urban areas is a place to build community and educational facilities. The primary personal motivation of individuals to take part in urban agriculture is the opportunity to socialize and preserve the culture of planting [20].

Yogyakarta City has the narrowest area than other level-II areas, which is $32.5 \mathrm{~km}^{2}$ or $1.025 \%$ of the total area of DIY Province. Despite being the narrowest area, the local government has great attention to the agricultural sector in urban areas. In addition, the enthusiasm of the city community toward the importance of using yards for food security, especially during the Covid-19 pandemic, has also increased [21]. Given that motivation is the initial foundation for everyone in carrying out their activities, it is crucial to conduct research to discover what motivates farmer group members and what factors underlie their motivation in utilizing urban yards? 


\section{Research Method}

This research was conducted in Yogyakarta City in Indonesia by taking locations in three districts of Kraton, Danurejan, and Kota Gede, with 45 respondents randomly taken from six farmer groups, two groups in each district. The respondents were people using their yards for farming vegetables, fruit plants, ornamental plants, medicinal plants, and members of farmer groups.

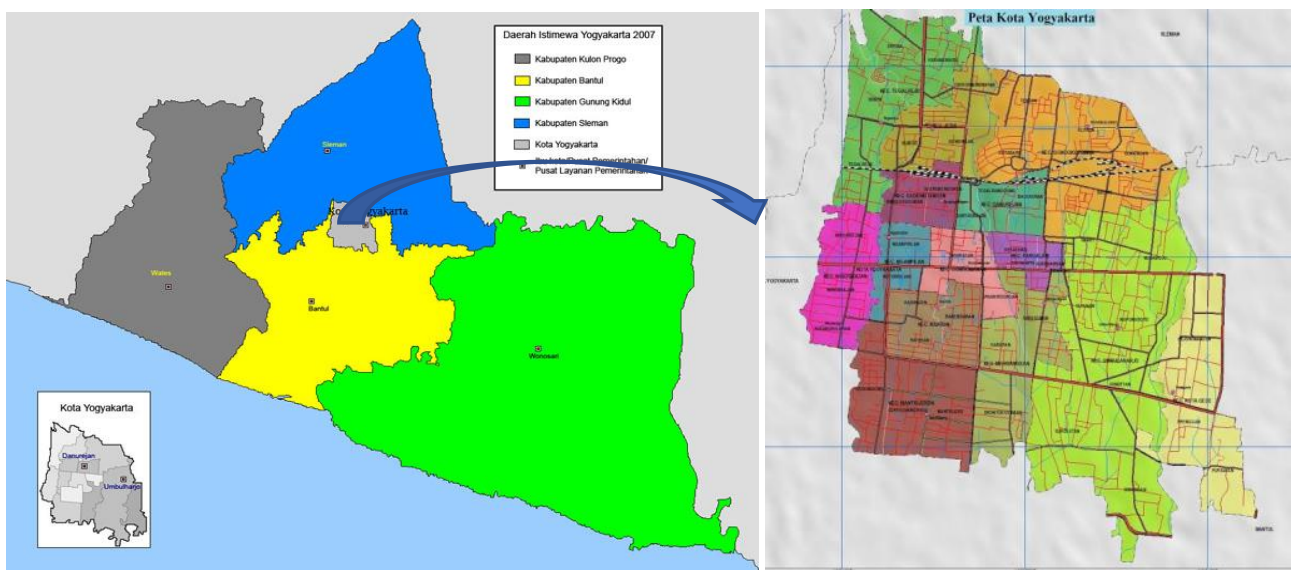

Fig. 1. Yogyakarta City Map

Table 1. Item Statement of Each Indicator

\begin{tabular}{|c|l|l|l|}
\hline No. & \multicolumn{1}{|c|}{ Existence } & \multicolumn{1}{c|}{ Relatedness } & \multicolumn{1}{c|}{ Growth } \\
\hline 1 & $\begin{array}{l}\text { Fulfilling family } \\
\text { food needs }\end{array}$ & $\begin{array}{l}\text { Actively participating in } \\
\text { group activities }\end{array}$ & $\begin{array}{l}\text { Using free time to utilize yards } \\
\text { to be more productive }\end{array}$ \\
\hline 2 & $\begin{array}{l}\text { Fulfilling family } \\
\text { nutrition }\end{array}$ & $\begin{array}{l}\text { Benefiting the } \\
\text { community }\end{array}$ & $\begin{array}{l}\text { Increasing knowledge and } \\
\text { insight about urban agriculture }\end{array}$ \\
\hline 3 & $\begin{array}{l}\text { Fulfilling primary } \\
\text { needs other than } \\
\text { food }\end{array}$ & $\begin{array}{l}\text { Exchanging ideas with } \\
\text { others }\end{array}$ & $\begin{array}{l}\text { Improving skills in urban } \\
\text { agriculture }\end{array}$ \\
\hline 4 & $\begin{array}{l}\text { Saving on family } \\
\text { expenses }\end{array}$ & $\begin{array}{l}\text { Strengthening social } \\
\text { relations with the } \\
\text { community and fellow } \\
\text { group members }\end{array}$ & $\begin{array}{l}\text { Obtaining hygienic and organic } \\
\text { food for the family }\end{array}$ \\
\hline 5 & Saving & $\begin{array}{l}\text { Collaborating with other } \\
\text { group members }\end{array}$ & Making beautiful yards \\
\hline 6 & $\begin{array}{l}\text { Having an additional } \\
\text { source of income }\end{array}$ & \multicolumn{2}{|l}{$\begin{array}{l}\text { Developing new technologies in } \\
\text { urban land use }\end{array}$} \\
\hline
\end{tabular}

This study employed a quantitative descriptive research method with a survey technique. Primary data were collected by interview using a structured questionnaire. Clayton P. Alderfer's ERG theory was applied to compile variables and indicators of motivation of farmer group members in using urban yards. Motivation consisted of three indicators: existence, relationship, and growth. The motivation was measured using a Likert Scale of items with a score of 1 to 5 , namely SI $=$ Very Want, $\mathrm{I}=$ Want, $\mathrm{N}=$ Neutral, $\mathrm{TI}=$ Do not Want, STI = Very Not Want. The answers were calculated, and percentages were utilized to categorize high, medium, and low motivation levels. Spearman Rank Correlation Coefficient analysis was employed to determine the factors influencing motivation. The motivation was 
the dependent variable, while the independent variables encompassed age, education, number of dependents, farming experience, yard area, group leader role, extension worker role, government role, and use of technology information.

\section{Results and Discussion}

\subsection{Demographics of Respondents}

To determine the motivation of the community in using urban yards in Yogyakarta, it is necessary to understand the characteristics of farmer group members, covering age, education, farming experience, and yard area.

Age is one aspect that determines a person's performance or achievement in doing a job. Age will affect physical ability and way of thinking. Generally, older people tend to be more difficult to accept something new than the younger ones. According to the developmental stage, the age group comprises 20-40 in early adulthood, 41-60 in middle adulthood, and 6180 in advanced age [22]. The frequency distribution of respondents based on age was dominated by farmer group members aging 49-60 years. Table 1 displays that 15 farmer group members are engaged in farming using yards, with ages between 49-60 years and a yield of $33.33 \%$. Age can affect the motivation of farmer group members in accepting science and technology in utilizing urban yards because age affects the ability to receive science and technology, which can be harmonized with the awareness and motivation of farmer group members to develop their farming [23].

Regarding education, it refers to the last formal education taken and proven by having a diploma. The level of formal education taken by farmer group members significantly affected their mindset toward knowledge, technology, and something new. The higher the level of formal education achieved, the higher the motivation and way of thinking and perspective on something. The distribution of respondents based on the level of formal education was dominated by members of farmer groups with higher education. The table above depicts that 19 farmer group members possess a high level of formal education, namely the university level.

Farming experience refers to the time length a farmer group member engages in farming activities. This experience was beneficial in sustaining farming. The more experience a farmer has, the more useful it is in farming sustainability. The more experience they have, the more skills or expertise they have in farming. The previous table depicts that 30 farmer group members $(66.67 \%)$ have farming experience under ten years, ranging from six months to nine years because urban agricultural management has developed recently. Hence, the experience of using yards has not found a productive point.

A yard can be defined as a piece of land located directly around the house with clear boundaries. Thus, all family members can easily utilize it in their spare time [24]. In this case, the yard area determines the farmer group members in utilizing it. Table 2 depicts 36 farmer group members $(80 \%)$ with the largest land area of $10-68 \mathrm{~m}^{2}$. It indicates that in urban areas, most people had limited land. However, with the narrow land, the city community could still grow crops by utilizing their yards. 
Tabel 2. Demographics of Respondents

\begin{tabular}{|c|c|c|}
\hline Item & Frequency (People) & Percentage $(\%)$ \\
\hline \multicolumn{3}{|l|}{ Age (Year) } \\
\hline $25-36$ & 3 & 6.67 \\
\hline $37-48$ & 13 & 28.89 \\
\hline $49-60$ & 15 & 33.33 \\
\hline $61-72$ & 12 & 26.67 \\
\hline $73-81$ & 2 & 4.44 \\
\hline Total & 45 & 100.00 \\
\hline \multicolumn{3}{|l|}{ Education } \\
\hline Elementary School & 8 & 17.78 \\
\hline Junior High School & 1 & 2.22 \\
\hline Senior High School & 17 & 37.78 \\
\hline University & 19 & 42.22 \\
\hline Total & 45 & 100.00 \\
\hline \multicolumn{3}{|c|}{ Farming Experience (years) } \\
\hline $0.6-9.6$ & 30 & 66.67 \\
\hline $9.7-18.4$ & 6 & 13.33 \\
\hline $18.5-27.2$ & 4 & 8.89 \\
\hline $27.3-36$ & 3 & 6.67 \\
\hline $36.1-44$ & 2 & 4.44 \\
\hline Total & 45 & 100.00 \\
\hline \multicolumn{3}{|l|}{ Yard Area $\left(\mathrm{m}^{2}\right)$} \\
\hline $10-68$ & 36 & 80.00 \\
\hline $69-127$ & 6 & 13.00 \\
\hline $128-186$ & 1 & 2.20 \\
\hline $187-245$ & 1 & 2.20 \\
\hline $246-300$ & 1 & 2.20 \\
\hline Total & 45 & 100.00 \\
\hline
\end{tabular}

\subsection{The Motivation of Farmer Group Members In Utilizing Urban Yards Based On Aldefer's ERG Motivation Theory}

\subsubsection{The needs for the existence}

Table 3 displays six statement items in the motivation to fulfill existence needs, encompassing meeting family food needs, especially during the covid-19 pandemic, fulfilling family nutrition, fulfilling primary needs other than food, saving on family expenses, saving, and having an additional source of income.

Table 3 exhibits that meeting family food needs and fulfilling family nutrition, especially during the Covid-19 pandemic, are in the very high category because food is a food source for humans and is a primary need, especially at present. Far food sources have raised concerns about the quality of their food [11]. Urban communities recognize that the food they produce is fresher, more nutritious, and healthier [25]. The wider health benefit is how farming in yards helps them psychologically instill discipline and patience as well as 
maintain physical health. Health benefits have been one of the motivations influencing farmer group members to utilize yards in urban areas [13]. The next indicator is meeting the primary needs other than food (clothing and housing), belonging to the medium category with an average score of 3.29. It implies that the motivation of the farmer group members was sufficient in meeting the needs of clothing and housing.

Table 3. Average Scores and Categories on the Existence Variable

\begin{tabular}{|l|l|c|c|c|}
\hline No & \multicolumn{1}{|c|}{ Item } & $\begin{array}{c}\text { Interval } \\
\text { Score }\end{array}$ & $\begin{array}{c}\text { Total } \\
\text { Score }\end{array}$ & \multirow{2}{*}{ Category } \\
\hline 1 & Fulfilling family food needs & $1-5$ & 4.36 & \\
\cline { 1 - 3 } 2 & Fulfilling family nutrition & $1-5$ & 4.20 & \\
\cline { 1 - 3 } 3 & Fulfilling primary needs other than food & $1-5$ & 3.29 & \multirow{2}{*}{ High } \\
\hline 4 & Saving on family expenses & $1-5$ & 4.11 & \\
\cline { 1 - 3 } 5 & Saving & $1-5$ & 3.82 & \\
\cline { 1 - 3 } 6 & Having an additional source of income & $1-5$ & 4.07 & \\
\hline & Total & $6-30$ & 23.85 & \\
\hline
\end{tabular}

Notes:

$\begin{array}{ll}\text { Low Motivation } & =1-9.99 \\ \text { Medium Motivation } & =10-19.99 \\ \text { High Motivation } & =20-30\end{array}$

Saving family expenses, saving, and having an additional source of income belonged to the high category. In other words, the motivation of the farmer group members was high because the produce from their yard was used for cooking or their consumption. Thus, they did not buy ingredients for cooking at the market due to social restrictions during the Covid19 pandemic. The plants grown were vegetable crops such as mustard greens, spinach, kale, lettuce, tomatoes, chilies, other vegetable crops, fruits, live pharmacies, and ornamental plants. The motivation of farmer group members to save during a pandemic was based on the uncertain economy of each family. Thus, they must manage the income and expenditure budget, resulting in a higher demand for future savings. Hence, the use of urban yards helped each family increase income or saving expenses to set aside for saving. The motivation of members of farmer groups to have an additional source of income was included in the high category, with a score of 4.07. Along with the development of technology, especially in the agricultural sector, it influenced business opportunities so that the agricultural sector was considered a profitable business.

\subsubsection{The needs for relatedness}

Table 4. Average Score and Category on the Relatedness Variable

\begin{tabular}{|l|l|c|c|c|}
\hline No & \multicolumn{1}{|c|}{ Item } & Interval Score & Total Score & Category \\
\hline 1 & Actively participating in group activities & $1-5$ & 4.27 & \\
\cline { 1 - 4 } 2 & Benefiting the community & $1-5$ & 4.36 & \multirow{2}{*}{ High } \\
\hline 3 & Exchanging ideas with others & $1-5$ & 4.49 & \\
\cline { 1 - 4 } & $\begin{array}{l}\text { Strengthening social relations with the } \\
\text { community and fellow group members }\end{array}$ & $1-5$ & 4.38 & \\
\cline { 1 - 4 } 5 & Collaborating with other group members & $1-5$ & 3.91 & \\
\hline & Total & $5-25$ & 21.41 & \\
\hline
\end{tabular}

Notes:

Low Motivation $\quad=1-9.99$

Medium Motivation $=10-19.99$

High Motivation $\quad=20-30$ 
The needs for relatedness encouraged members of the farmer groups to interact and relate to other farmers or people outside the farmer groups. In the relatedness variable, five indicators were applied to measure the motivation level of farmer group members. The indicators comprised: actively participating in group activities, benefiting the community, exchanging ideas with others, strengthening social relations with the community and fellow farmer groups, and collaborating with other group members.

The role of the group leader, who always invited each member to participate in every activity held by the group actively, be it counseling or farming, has been one of the motivation factors. The motivation of farmer group members stating that urban yards were beneficial to the community was high. Everyone might want to be useful to others, both in material and non-physical material. Therefore, with the utilization of yards, members of the farmer groups could exchange ideas with each other and make the air fresher and the environment more beautiful. Accordingly, the motivation of farmer group members to exchange ideas with others was also in the high category because they could share information on how to make their yards more aesthetically pleasing. In addition, the importance of food security by utilizing yards to grow vegetables and fruits was quite extraordinary. The motivation of members of farmer groups to strengthen social relations with the community and farmer groups belonged to the high category. Emotional ties between fellow people were required for survival. Farmer group members could share seeds and other things to strengthen their relationships. The motivation of farmer group members to cooperate with other group members was included in the high category. They had WhatsApp groups to provide information; thus, cooperation on farming, maintenance, and marketing was established.

\subsubsection{The needs for growth}

The needs for growth encouraged members of farmer groups to develop for the better, such as developing ways of thinking and self-potential in the hope of being useful for themselves, their families, and others. Variables in determining the growth motivation or growth of farmer group members consisted of six statement items: utilizing home yards to be more productive, increasing knowledge and insight about urban agriculture, increasing skills about urban agriculture, obtaining hygienic and organic food for the family, and making beautiful yards, and developing new technologies in urban land use.

Table 5. The Average Score and Category On The Growth Variable

\begin{tabular}{|l|l|c|c|c|}
\hline No & \multicolumn{1}{|c|}{ Item } & Interval Score & Total Score & Category \\
\hline 1 & $\begin{array}{l}\text { Using free time to utilize yards to be more } \\
\text { productive }\end{array}$ & $1-5$ & 4.40 & \\
\hline 2 & $\begin{array}{l}\text { Increasing knowledge and insight about } \\
\text { urban agriculture }\end{array}$ & $1-5$ & 4.31 & \multirow{2}{*}{ High } \\
\hline 3 & Improving skills in urban agriculture & $1-5$ & 4.27 & \\
\hline 4 & $\begin{array}{l}\text { Obtaining hygienic and organic food for } \\
\text { the family }\end{array}$ & $1-5$ & 4.42 & \\
\hline 5 & Making beautiful yards & $1-5$ & 4.49 & \\
\hline 6 & $\begin{array}{l}\text { Developing new technologies in urban } \\
\text { land use }\end{array}$ & $1-5$ & 2.24 & \\
\hline & Total & $6-30$ & 26.13 & \\
\hline
\end{tabular}

Notes:

Low Motivation $\quad=1-9.99$

Medium Motivation $\quad=10-19.99$

High Motivation $\quad=20-30$ 
The motivation of the farmer group members to be productive by utilizing yards was in the high category, especially during this Covid-19 pandemic, where people have to limit outdoor activities. The motivation of farmer group members to increase their knowledge and insight about urban agriculture was also high, so was their motivation to improve skills in urban agriculture. With the increasing knowledge and insight about urban agriculture, farmer group members became more skilled in applying their knowledge because the knowledge, especially technology in agriculture, continued to grow rapidly. Similarly, the motivation of members of farmer groups to create beautiful yards also belonged to the high category. Making the environment more beautiful, comfortable, and pleasing to the eye was undoubtedly the dream of most of them. A good environment would impact human health both physically and mentally. Indeed, all farmer group members wanted their yards to look pleasing and aesthetic. Moreover, their motivation to develop new technology in urban land use was also high, signifying their eagerness.

Table 6 exhibits that the motivation for the needs for existence obtains a total score of 23.85 , being in the high category. The needs for existence consisted of six indicators to determine the motivation level. This study is in line with [26], obtaining the needs for existence of $55.71 \%$, meaning that members of the farmer group in fulfilling physiological needs such as security and food availability were included in the high category. It was proven from most farmer group members choosing to consume vegetables instead of selling them.

Table 6. Motivation Score of Farmer Group Members in Utilizing Urban Yards

\begin{tabular}{|l|c|c|c|}
\hline ERG Motivation & Interval Score & Total Score & Category \\
\hline Existence & $6-30$ & 23.85 & High \\
\hline Relatedness & $5-25$ & 21.41 & High \\
\hline Growth & $6-30$ & 26.13 & High \\
\hline
\end{tabular}

The needs for relatedness obtained a score of 21.41 , belonging to the high category. It indicates that members of farmer groups were motivated to fulfill the needs for social relations or relationships with other farmer group members, consisting of five indicators to measure their motivation level. Members of urban farmer groups had high motivation to relate to members of other farmer groups socially. It means that utilizing urban yards had a positive social impact, such as a sense of security in a farmer group, close ties between farmer group members, and feeling recognized in the community or group.

Growth needs obtained an average score of 26.13 , with a high category, indicating that members of farmer groups had high motivation to develop urban agriculture in terms of creativity, productivity, and the environment. It is in line with [25], revealing that the motivation for growth needs was enormous, namely the desire of farmer group members to gain knowledge and insight. It implies that knowledge and insight were essential for farmer group members to develop.

\subsubsection{Factors Related To The Motivation of Farmer Group Members In Utilizing Urban Yards During The Covid-19 Pandemic In Yogyakarta City}

Below are the motivation factors of farmer group members in using urban yards. To determine the relationship, the Spearman Rank Correlation Coefficient test was performed. 
Tabel 7. Factors Related to the Motivation of Farmer Group Members in Utilizing Urban

\begin{tabular}{|l|c|c|c|}
\hline \multicolumn{1}{|c}{ Variable } & Existence & Relatedness & Growth \\
\hline Age & & & \\
\hline rs & -0.198 & -0.231 & -0.109 \\
\hline Sig. & $0.097^{*}$ & $0.063^{*}$ & 0.238 \\
\hline Education & & & \\
\hline rs & -0.037 & 0.195 & 0.071 \\
\hline Sig. & 0.404 & 0.100 & 0.323 \\
\hline Farming Experience & & & \\
\hline rs & -0.052 & -0.133 & -0.055 \\
\hline Sig. & 0.368 & 0.192 & 0.360 \\
\hline Yard Area & & & \\
\hline rs & 0.123 & -0.121 & -0.037 \\
\hline Sig. & 0.210 & 0.213 & 0.406 \\
\hline Group Leader Role & & & \\
\hline Rs & -0.225 & -0.332 & -0.227 \\
\hline Sig. & $0.069^{*}$ & $0.013^{* *}$ & $0.067^{*}$ \\
\hline Agricultural Extension Worker Role & & & \\
\hline Rs & -0.216 & -0.337 & -0.170 \\
\hline Sig. & $0.077^{*}$ & $0.012^{* *}$ & 0.132 \\
\hline Government Role & & & \\
\hline Rs & -0.227 & -0.114 & -0.063 \\
\hline Sig. & $0.067^{*}$ & 0.228 & 0.341 \\
\hline Use of Information Technology & & & \\
\hline rs & -0.269 & -0.257 & -0.196 \\
\hline Sig. & $0.037^{* *}$ & $0.044^{* *}$ & $0.099^{*}$ \\
\hline
\end{tabular}

Note: *** Significant $\alpha=1 \% *$ Significant $\alpha=10 \%$

** Significant $\alpha=5 \%$

\subsubsection{Age}

The age factor had a significant relationship to existence and relationship but did not significantly affect growth motivation. In this case, age had a significant relationship to motivation for existence because it affected physical, psychological, and biological abilities in carrying out productive activities. In urban areas, the older a person is, the more activities are required to fill their time, one of which is utilizing yards for planting. There is no set age limit in meeting the relatedness motivation or needs, as long as they can meet the relatedness needs at any time [26]. The age factor did not affect the motivation of farmer group members to meet growth needs because regardless of the age of farmer group members, motivation to meet growth needs was still required in seeking information, attending training, or agricultural counseling to increase their intellectual and practical growth. In this study, members of the farmer group were dominated by those aging 49-60, totaling 15 out of 45 respondents. This age range is not in the productive age. However, the study results uncovered that, on average, the motivation of farmer groups members to utilize urban yards was high. It implies that regardless of age, members of farmer groups still wanted to utilize their yards for planting, both on a production and consumption scale, because, during this Covid-19 pandemic, people have been tired of social restrictions, making them look for beneficial activities. 


\subsubsection{Education}

Overall, the educational factor had no significant relation with the motivation of existence, relatedness, and growth of farmer group members. In other words, the education level did not affect their motivation in utilizing urban yards. The education level of farmer group members in this study was dominated college-level education. The higher the education of a farmer group member, the more they assume that the narrow urban land not intended for the agricultural sector could not generate sufficient income for the daily needs; even urban yards were only utilized on the sidelines of their busy work.

\subsubsection{Farming Experience}

The farming experience factor did not significantly affect the motivation of existence, relatedness, and growth. It signifies the absence of a relationship between farming experience and the motivation of farmer group members in using urban yards. Farming experience in this study was dominated by those with experiences ranging 0.6-9.6 years, as many as 30 out of 45 respondents. In short, farming experience had no significant relationship with their motivation in using urban yards as urban agriculture has been developed recently. Therefore, the experience did not affect them in applying new methods and new technology.

\subsubsection{Yard Area}

The yard area factor did not significantly influence the motivation of existence, relatedness, and growth. In other words, narrow yards were not an obstacle for members of farmer groups to use their yards.

\subsubsection{Group Leader Role}

The role of farmer group leader had a significant relationship with the motivation of existence, relatedness, and growth. It was included in the factors influencing the motivation of members of farmer groups, formed based on a common goal as a forum for interaction between members of farmer groups, members of farmer groups and related institutions, and members of farmer groups with extension workers. Thus, they became a learning vehicle to support the agricultural system in improving farm management skills, experience, and knowledge. It is in line with [27]. Moreover, the group leader also played a role in encouraging each member to participate in the management of urban yards.

\subsubsection{Extension Role}

The instructor role had a significant relationship with the motivation of existence and relatedness. However, it had no significant relation with growth motivation. The intensity of the extension worker role motivated the farmer group members, resulting in the response members of the farmer group to farming getting stronger. The extension's visit to the field affected the absorption of information and the use of new technology.

\subsubsection{Government Role}

The government role had a significant relation with the existence motivation. Unfortunately, it had no significant relation with relatedness and growth motivation. The heads or members of the farmer groups revealed that the assistance for agricultural facilities from the 
government was uneven and decreased every year. It made them not rely on the government regarding the development of urban agriculture. However, their enthusiasm and motivation to utilize urban yards remained high, especially during this Covid-19 pandemic.

\subsubsection{Use of Information Technology}

The role of technology had a significant relation with the motivation of existence, relatedness, and growth. People nowadays are getting familiar with the technology. Considering that all forms of information were available in electronic form, information technology has supported applying narrow land farming methods. This study results revealed that 27 out of 45 respondents belonged to the category of people frequently using technology, whether it was cellphones, laptops, television, and even internet networks.

\section{Conclusions and Recommendation}

The motivation of farmer groups members to utilize urban yards, as seen from the motivation of existence, relatedness, and growth needs, belonged to the high category. It indicates that urban agriculture had the potential to be developed. The results of the Spearman Rank Correlation Coefficient analysis unveiled that the factors related to the motivation of the farmer group members age the role of the group leader, the extension workers, and information technology. The utilization of yards in Yogyakarta had the potential to be developed by optimizing the role of the chairman, extension workers, and the government and using information technology.

Acknowledgment. The authors would like to deliver enormous gratitude to Universitas Muhammadiyah Yogyakarta for supporting this study.

\section{References}

1. Primahendra R, Sumbogo TA, Lensun RA, Purwanto A (2020) Handling Corona Virus Pandemic In The Indonesian Political Context: A Grounded Theory Study. Eur J Mol Clin Med 7:113-125

2. Bidarti A (2021) Survive of the Indonesia farmers in during the Covid-19 Pandemic: Findings of the South Sumatra. E3S Web Conf 232: https://doi.org/10.1051/e3sconf/202123201019

3. Prasada IY, Masyhuri M (2019) The Conversion of Agricultural Land in Urban Areas (Case Study of Pekalongan City, Central Java). Agrar J Agribus Rural Dev Res 5: https://doi.org/10.18196/agr.5280

4. Mayasari K, Sente U, Ammatilah CS (2015) Analisis Motivasi Petani Dalam Mengembangkan Pertanian Perkotaan di Provinsi DKI Jakarta. Bulletin Pertanian Perkotaan 5:16-24

5. Mohri H, Lahoti S, Saito O, et al. (2013) Assessment of ecosystem services in homegarden systems in Indonesia, Sri Lanka, and Vietnam. Ecosyst Serv 5:124-136. https://doi.org/10.1016/j.ecoser.2013.07.006

6. Gusfarina DS, Irham I (2019) Mengukur Tingkat Motivasi Masyarakat Terhadap Pemanfaatan Pekarangan Untuk Pertanian Perkotaan Di Kota Yogyakarta. J Kawistara 9:208. https://doi.org/10.22146/kawistara.41013

7. Ciftcioglu GC (2017) Assessment Of The Resilience Of Socio-Ecological Production Landscapes And Seascapes: A Case Study From Lefke Region Of North Cyprus. Ecol 
Indic 73:128-138. https://doi.org/10.1016/j.ecolind.2016.09.036

8. Setyowati DL (2008) (The Micro Climate and The Need of Green Open Space for The City of Semarang). J Mns dan Lingkungan 15:125-140. https://doi.org/10.22146/jml.18685

9. Corrigan MP (2011) Growing what you eat: Developing community gardens in Baltimore, Maryland. Appl Geogr 31:1232-1241. https://doi.org/10.1016/j.apgeog.2011.01.017

10. Gauder M, Hagel H, Gollmann N, et al. (2019) Motivation and background of participants and providers of self-harvest gardens in Germany. Renew Agric Food Syst 34:534-542. https://doi.org/10.1017/S174217051800008X

11. Egli V, Oliver M, Tautolo ES (2016) The development of a model of community garden benefits to wellbeing. Prev Med Reports 3:348-352. https://doi.org/10.1016/j.pmedr.2016.04.005

12. Hallett S, Hoagland L, Toner E (2016) Urban agriculture: Environmental, economic, and social perspectives

13. Poulsen MN, Neff RA, Winch PJ (2017) The multifunctionality of urban farming: perceived benefits for neighbourhood improvement. Local Environ 22:1411-1427. https://doi.org/10.1080/13549839.2017.1357686

14. O’Sullivan CA, Bonnett GD, McIntyre CL, et al. (2019) Strategies to improve the productivity, product diversity and profitability of urban agriculture. Agric. Syst. 174:133-144

15. Ramalingam L, Sharifuddin J, Abidin Z, Ali F (2018) Community Garden Programme An Analysis of Volunteers , Motivations And Age Groups. 23:48-53. https://doi.org/10.9790/0837-2306014853

16. Battersby J, Marshak M (2013) Growing Communities: Integrating the Social and Economic Benefits of Urban Agriculture in Cape Town. Urban Forum 24:447-461. https://doi.org/10.1007/s12132-013-9193-1

17. Trendov NM (2018) Comparative Study On The Motivations That Drive Urban Community Gardens In Central Eastern Europe. Ann Agrar Sci 16:85-89. https://doi.org/10.1016/j.aasci.2017.10.003

18. Wulandari R, Witjaksono R, Inekewati R (2021) Community Participation in the Development of Urban Farming in Yogyakarta City. E3S Web Conf 232:01024. https://doi.org/10.1051/e3sconf/202123201024

19. Santrock (2002) Life Span Develovment (Perkembangan Masa Hidup). Erlangga, Jakarta

20. Dalmiyatun T, Eddy BT, Sumekar W, Mardiningsih D (2018) Motivation of farmers to cultivate organic rice in Central Java. IOP Conf Ser Earth Environ Sci 102: https://doi.org/10.1088/1755-1315/102/1/012043

21. Ashari N, Saptana N, Purwantini TB (2016) Potensi dan Prospek Pemanfaatan Lahan Pekarangan untuk Mendukung Ketahanan Pangan. Forum Penelit Agro Ekon 30:13. https://doi.org/10.21082/fae.v30n1.2012.13-30

22. Gauder M, Hagel H, Gollmann N, et al. (2018) Motivation and background of participants and providers of self-harvest gardens in Germany. Renew Agric Food Syst 1-9. https://doi.org/10.1017/S174217051800008X

23. Othman N, Latip RA, Ariffin MH (2019) Motivations For Sustaining Urban Farming Participation. Int J Agric Resour Gov Ecol 15:45. https://doi.org/10.1504/ijarge.2019.10021353 